\title{
Development and Validation of Spectrophotometric Methods for the Determination of Mesalazine in Pharmaceutical Formulation
}

\section{Fatima Altayib Alasha Abdalla and Abdalla Ahmed Elbashir*}

Chemistry Department, Faculty of Science, University of Khartoum, Sudan

\begin{abstract}
Two simple, accurate and precise spectrophotometric methods for the quantitative analysis of mesalazine (MSZ) in pharmaceutical formulation have been described. The first method $(A)$ is based on the charge transfer reaction with alizarin red sulphonate (ARS) in the solution of $\mathrm{pH} 8.0$ to form a violet product showing maximum absorbance at $600 \mathrm{~nm}$. The second method $(B)$ is a derivatisation method involving reaction of MSZ with 1,2-naphthoquinone-4sulphonate (NQS) in alkaline medium at $\mathrm{pH} 12.0$ to form an orange product exhibiting maximum absorbance at 470 $\mathrm{nm}$. All variables affecting the reactions were studied and optimized. Beer's law was obeyed in the concentration ranges of $15-97.5$ and $2-22 \mu \mathrm{g} / \mathrm{mL}$ for methods $A$ and B, respectively. The molar absorptivity, Sandell sensitivity, detection and quantification limits were calculated. The two methods were successfully applied to the determination of MSZ in pharmaceutical formulation.
\end{abstract}

Keyword: Spectrophotometric; Mesalazine; Pharmaceutical formulation; 1,2-naphthoquinone-4-sulphonate (NQS)

\section{Introduction}

Mesalazine (MSZ), chemically known as 5-amino-2hydroxybenzoic acid, is an anti-inflammatory drug used to treat and also maintain the remission of mild to moderate ulcerative colitis or Crohn's disease [1,2]. MSZ has been shown to be a potent scavenger of reactive oxygen species that play a significant role in the pathogenesis of inflammatory bowel disease, inhibition of natural killer cell activity, inhibition of antibody synthesis, inhibition of cyclooxygenase and lipoxygenase pathways and impairment of neutrophil function $[3,4]$. A number of analytical methods have been reported for the determination of MSZ in pharmaceutical dosage forms and biological fluids including spectrofluorometric [5], micellar electrokinetic chromatography [6], differential pulse voltammetry [7], HPLC [4,8-12], LC/MS/MS [13] and spectrophotometric [14-20]. Chromatographic methods have been extensively used and recommended. However these methods generally require complex and expensive equipment, provision for use and disposal of solvents, labor-intensive sample preparation procedures and personal skills in chromatographic techniques. Spectrophotometric methods are the most convenient technique because of their inherent simplicity, high sensitivity, low cost, and wide availability in quality control laboratories. However, the spectrophotometric methods [14-20] that have been reported for the determination of MSZ in their pharmaceutical formulations were associated with some major disadvantages, such as lack of sensitivity, tedious extraction procedures, heating, cooling and time consumption. In this paper, development and validation of two new spectrophotometric methods for the determination of MSZ in pharmaceutical tablets that overcome these drawbacks will be described.

\section{Materials and Methods}

\section{Apparatus}

All of the spectrophotometric measurements were made with a Double beam UV 1800 ultraviolet visible spectrophotometer provided with matched $1-\mathrm{cm}$ quartz cells (SHIMATZU- Japan) with temperature maintained at $25^{\circ} \mathrm{C}$. $\mathrm{pH}$ was determined using a model pH211 pH meter (Hanna, Italy). Thermostatically controlled waterbath (LAUDA, ecoline RE 220).

\section{Materials}

All chemicals were of analytical or HPLC grade. Distilled water was used in all experiments. Chemicals (suppliers) were as follows: The standard of MSZ was obtained from Sigma-Aldrich, tablet formulation Pentasa (Pharbil Pharma Bielefeld, Germany (Marketing Authorization Holder : Ferring GmbH, Kiel, Germany) was purchased from a local pharmacy with labeled amount $500 \mathrm{mg}$ MSZ, Alizarin Red Sulphonate (ARS) [Hopkin \& Williams LTD (England)], sodium 1,2-naphthoquinone-4-sulphonate (NQS) was purchased from [Aldrich Chemical Co., St. Louis, USA].

\section{Preparation of reagents and solutions}

Stock standard solution of Mesalazine (MSZ): An accurately weighed amount $0.100 \mathrm{~g}$ of MSZ was dissolved in $30 \mathrm{~mL}$ water then transferred into a $100 \mathrm{~mL}$ standard flask, completed to the mark with ethanol for method A (ratio of water to ethanol was 30:70)and distilled water for method B to obtain a stock solution of $(1000 \mu \mathrm{g} /$ $\mathrm{mL}$ ). The stock solutions were further diluted with the same solvent to obtain working solutions of (150 and $200 \mu \mathrm{g} / \mathrm{mL}$ ), for method A and $B$ respectively.

Standard solution of Alizarin Red Sulphonate (ARS): An accurately weighed amount ( $0.5134 \mathrm{~g})$ of ARS was dissolved in 30:70 water and ethanol, transferred into a $100 \mathrm{~mL}$ standard flask, completed to the mark with the same solvent to obtain a solution of $15 \times 10^{-3} \mathrm{~mol} / \mathrm{L}$. The solution was freshly prepared and protected from light during use.

Sodium 1, 2-Naphthoquinone-4-Sulfonic Solution (NQS): An accurately weighed $0.1041 \mathrm{~g}$ of NQS was dissolved in distilled water, transferred into a100 $\mathrm{mL}$ standardflask and diluted to the mark with

*Corresponding author: Abdalla A Elbashir, Chemistry Department, Faculty of Science, University of Khartoum, PO Box 321, Khartoum, 11115, Sudan, E-mail: hajaae@yahoo.com

Received January 24, 2014; Accepted March 21, 2014; Published March 24, 2014

Citation: Alasha Abdalla FA, Elbashir AA (2014) Development and Validation of Spectrophotometric Methods for the Determination of Mesalazine in Pharmaceutical Formulation. Med chem 4: 361-366. doi:10.4172/2161-0444.1000166

Copyright: (c) 2014 Alasha Abdalla FA, et al. This is an open-access article distributed under the terms of the Creative Commons Attribution License, which permits unrestricted use, distribution, and reproduction in any medium, provided the original author and source are credited. 
distilled water and mixed well to prepare $\left(4 \times 10^{-3} \mathrm{~mol} / \mathrm{L}\right)$. The solution was freshly prepared and protected from light during use.

Buffer solutions: Buffer solution of $\mathrm{pH} 8.0$ was prepared by adding $4.49 \mathrm{~mL}$ of $0.1 \mathrm{~mol} / \mathrm{L} \mathrm{HCl}$ and $95.51 \mathrm{~mL}$ of $0.1 \mathrm{~mol} / \mathrm{L} \mathrm{Na}_{2} \mathrm{HPO}_{4}$ and adjusting to $\mathrm{pH} 8.0, \mathrm{pH} 12.0$ was prepared by adding $100 \mathrm{~mL} 0.05 \mathrm{M}$ $\mathrm{Na}_{2} \mathrm{HPO}_{4}$ and $53.8 \mathrm{~mL}$ of $0.1 \mathrm{M} \mathrm{NaOH}$, and made up to $200 \mathrm{~mL}$ with distilled water. Other buffer solutions were also prepared according to literature method.

Sample solution: A sample of finely powdered tablet nominally equivalent to $0.100 \mathrm{~g} \mathrm{MSZ}$ was dissolved in about $30 \mathrm{~mL}$ distilled water in a $100 \mathrm{~mL}$ volumetric flask. Then swirled, sonicated for $15 \mathrm{~min}$, then filled to the volume with ethanol for method A (ratio of water to ethanol was 30:70) and distilled water for method B, The contents were mixed well and filtered. This prepared solution was diluted quantitatively to obtain a suitable concentration for the analysis.

\section{Assay procedures}

Method using ARS (Method A): Aliquots of MSZ solution were added to10 mLvolumetric flasks to give final concentrations of (15-97.5 $\mu \mathrm{g} / \mathrm{mL})$. $2.0 \mathrm{~mL}$ Buffer solution of $\mathrm{pH} 8.0$ was added followed by 1.0 $\mathrm{mL}$ ARS solution $\left(15 \times 10^{-3} \mathrm{~mol} / \mathrm{L}\right)$. The reaction was allowed to proceed at temperature $40^{\circ} \mathrm{C}$ for $10 \mathrm{~min}$ after which the reaction mixture was made up to the mark with water and the absorbance was measured at600nm against a water blank similarly prepared.

Method using NQS (Method B): Aliquots of MSZ solution was added to $10 \mathrm{~mL}$ volumetric flasks to give final concentrations of $(2-22$ $\mu \mathrm{g} / \mathrm{mL}$ ). $1.0 \mathrm{~mL}$ Buffer solution of $\mathrm{pH} 12.0$ was added followed by 1.0 $\mathrm{mL} \mathrm{NQS} \mathrm{solution}\left(4 \times 10^{-3} \mathrm{~mol} / \mathrm{L}\right)$. The reaction was allowed toproceed at room temperature for 10 minutes after which there action mixture was made up to the mark with water and the absorbance was measured at $470 \mathrm{~nm}$ against blank similarly prepared.

\section{Stoichiometry of the reaction (Job's method)}

Stoichiometry of the reaction of MSZ with ARS and NQS was established by Job's method of continuous variation [21]. Equimolar aqueous solutions of MSZ with ARS and NQS $\left(3 \times 10^{-3}, 2.5 \times 10^{-3} \mathrm{~mol} / \mathrm{L}\right.$ respectively ) were prepared in $10 \mathrm{~mL}$ volumetric flasks containing complementary proportions: $(0: 10,1: 9,2: 8,3: 7,4: 6,5: 5,6: 4,7: 3$, $8: 2,9: 1,10: 0)$. The solutions of method A and B were further treated as described under the general recommended procedure.

\section{Results and Discussion}

\section{Method A}

Alizarin Red S (ARS) has been used as a color-developing reagent in the spectrophotometric determination of pharmaceutical amines [22-26]. The reaction of MSZ with ARS to produce a violet colored charge transfer product of the $n-\pi$ type, this compound is considered to be an intermediate molecular association complex which dissociates in the corresponding radical anion in the solvent.

At optimum conditions the radical anion (absorbing species) in the medium after mixing of the reagent and showed maximum absorption at 600 (Figure 1). The absorbance was found to increase linearly with increasing concentration of MSZ.

The effect of $\mathrm{pH}$ was studied by forming the colored product in the presence of various $\mathrm{pH}$ the absorbance of the proton transfer product was measured. Figure 2 shows that at $\mathrm{pH}$ from 1.0 to 4.0, no MSZ-ARS product was formed whereas at $\mathrm{pH}$ greater than $\mathrm{pH} 4.0$ the absorbance increased rapidly with increasing $\mathrm{pH}$ up to $\mathrm{pH} 8.0$ and then decrease, after $\mathrm{pH}$ greater than 8.0 , the decrease in absorbance of the product was observed. The maximum absorbance was attained at $\mathrm{pH}$ value of 8.0.

The reaction was found to be dependent on ARS concentration with the absorbance of the reaction solution increasing as the ARS concentration increased. Maximum absorbance was attained on using $1.0 \mathrm{~mL}$ of $15 \times 10^{-3} \mathrm{~mole} / \mathrm{L}$ ARS above which it decreased. Therefore, this concentration was used in all subsequent work Figure 3.

The reaction time was determined by following the color development at room temperature and in thermostatically controlled water-bath adjusted at temperature in range from $\left(30-90^{\circ} \mathrm{C}\right)$. The highest absorbance is obtained $40^{\circ} \mathrm{C}$ for 10 minutes.

\section{Method B}

MSZ exhibits maximum absorbance $\left(\lambda_{\max }\right)$ at $298 \mathrm{~nm}$. Being in the ultraviolet, absorbance at this wavelength is susceptible to interference from co-extracted excipients in the tablet formulation. Accordingly,

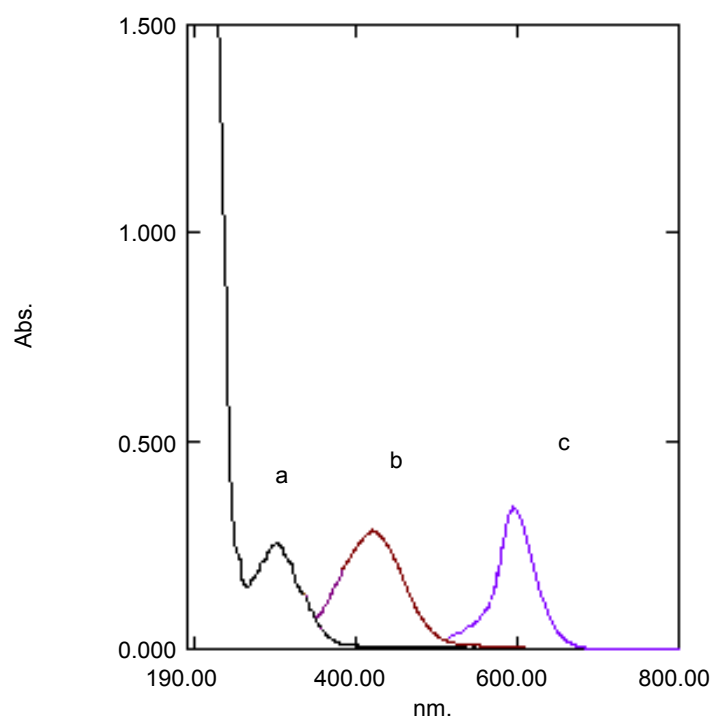

Figure 1: Absorption spectra of MSZ $(50 \mu \mathrm{g} / \mathrm{mL})$ against blank (a), ARS against blank (b), and the reaction product of MSZ $(50 \mu \mathrm{g} / \mathrm{mL})$ with ARS against reagent blank (c).

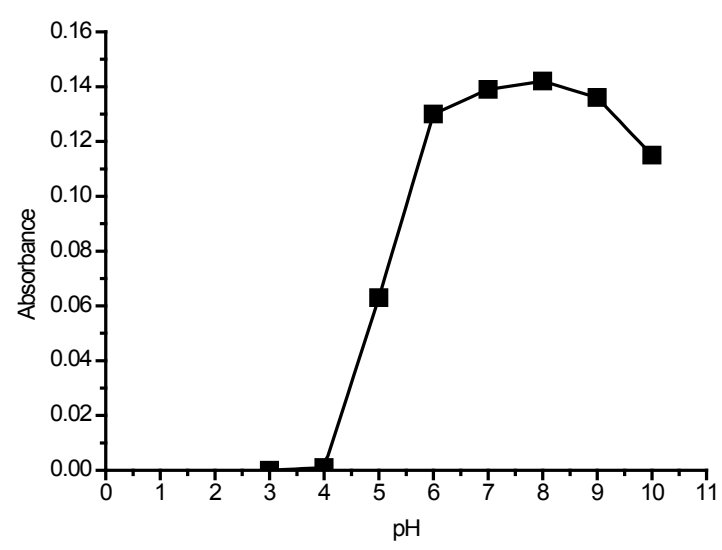

Figure 2: Effect of $\mathrm{pH}$ on the reaction of $\mathrm{MSZ}$ with ARS, $(30 \mu \mathrm{g} / \mathrm{mL}$ of $\mathrm{MSZ}$, $1.0 \mathrm{~mL}$ buffer solution, $1.0 \mathrm{~mL}$ of ARS $13 \times 10^{-3} \mathrm{~mol} / \mathrm{L}$ ) at room temperature, and reaction time $10 \mathrm{~min}$. 
derivatization of MSZ to produce a chromophore absorbing more in the visible region was appropriate. MSZ contains a primary aliphatic amino group, which is suitable for derivatization by NQS, an analytical chromogenic reagent for the determination of primary and secondary amines [27-35]. MSZ was found to react with NQS under the experimental conditions to form an orange colored product exhibiting $\lambda_{\max }$ at $470 \mathrm{~nm}$ (Figure 4). Under the optimum reaction conditions, the absorbance was found to obey the Beer-Lambert law.

The effects of $\mathrm{pH}$ on the reaction of MSZ with (NQS) were examined by varying the $\mathrm{pH}$ from 4.0 to 13.0 , the results revealed that the absorbance increased with increasing up to $\mathrm{pH} 12$. The maximum readings were attained at $\mathrm{pH}$ value of 12.0 . At $\mathrm{pH}$ value more than 12.0 , a decrease in the reading occurred. This was attributed probably to the increase in the amount of hydroxide ion that holds back the reaction of MSZ with NQS [33] (Figure 5).

The effect of temperature on the reaction was also studied by varying the temperature from $25^{\circ} \mathrm{C}$ to $90^{\circ} \mathrm{C}$. The highest absorbance is obtained at room temperature for $10 \mathrm{~min}$.

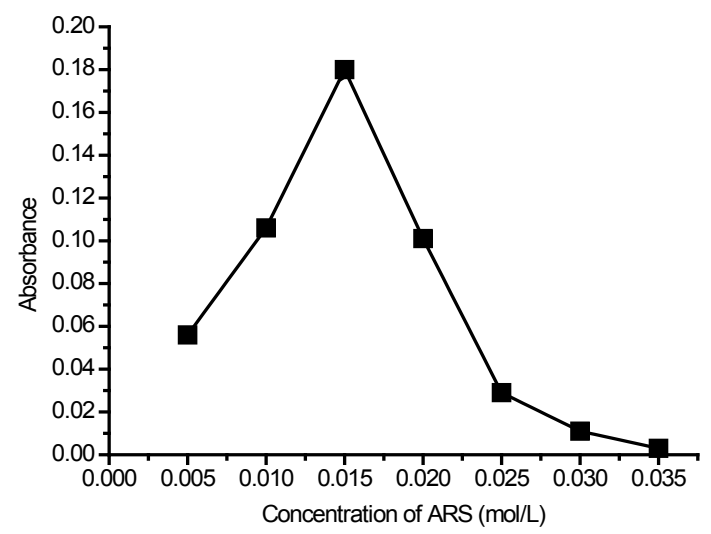

Figure 3: Effect of ARS concentration on the reaction with $\mathrm{MSZ}(30 \mu \mathrm{g} / \mathrm{mL}$ of MSZ, $2.0 \mathrm{~mL}$ buffer solution $(\mathrm{pH} 8)$, at $40^{\circ} \mathrm{C}$, and reaction time $10 \mathrm{~min}$.

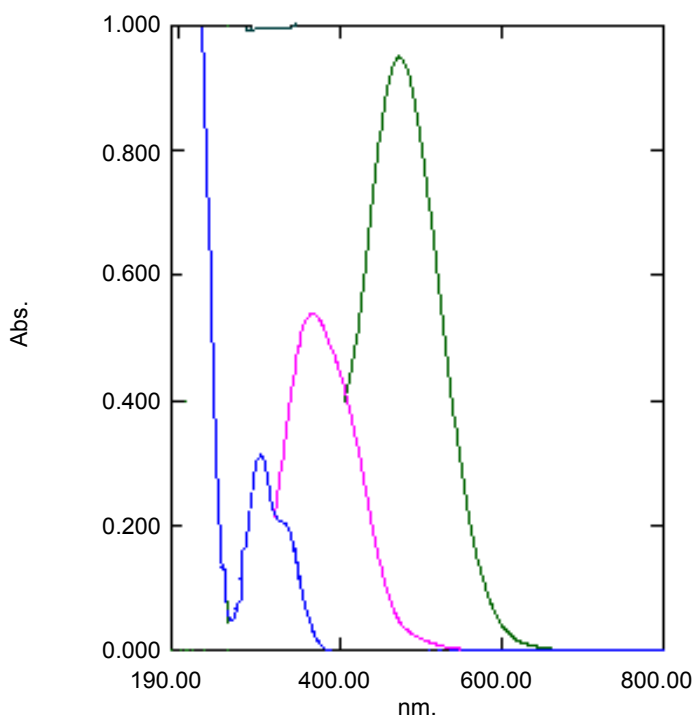

Figure 4: Absorption spectra of $\mathrm{MSZ}(25 \mu \mathrm{g} / \mathrm{mL})$ against water (blue line), NQS against water (pink line), and the reaction product of MSZ $(25 \mu \mathrm{g} / \mathrm{mL})$ with NQS against reagent blank (green line).

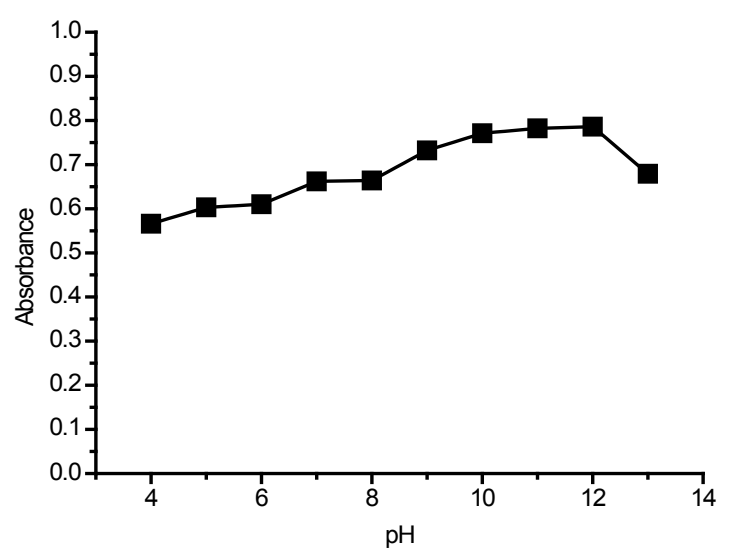

Figure 5: Effect of $\mathrm{pH}$ on the reaction of MSZ with NQS, $20 \mu \mathrm{g} / \mathrm{mL}$ of MSZ, $1.0 \mathrm{~mL}$ buffer solution, $1.0 \mathrm{~mL}$ of NQS $\left(5 \times 10^{-3} \mathrm{~mol} / \mathrm{L}\right)$ at room temperature $\left(25^{\circ} \mathrm{C}\right)$, and reaction time $10 \mathrm{~min}$.

The effect of different NQS concentrations on the absorbance of product was studied; it is evident that the absorbance increases with increasing NQS concentration and reached maximum on using $1 \mathrm{ml}$ of $4 \times 10^{-3} \mathrm{~mol} / \mathrm{L}$ NQS. Therefore, this concentration was used in all subsequent work (Figure 6).

\section{Stoichiometry of the reaction (Job's method)}

Under the optimum conditions shown in Table 1, the stoichiometric ratio between MSZ and each of investigated reagents (ARS, NQS) was found to be 1:1 (Figures 7 and 8). Based on this ratio, the reaction pathways were postulated to be proceeded as shown in scheme 1 and scheme 2 .

\section{Validation of the proposed method}

Linearity and sensitivity: Calibration curves for Methods A and $B$ in the ranges $15-97.5 \mu \mathrm{g} / \mathrm{mL}$ and $2-22 \mu \mathrm{g} / \mathrm{mL}$ were linear with correlation coefficients $\left(\mathrm{r}^{2}\right)$ of 0.9986 and 0.9997 for methods A and B, respectively. The molar absorptivities $(\varepsilon)$ at $600 \mathrm{~nm}$ and $470 \mathrm{~nm}$ for Methods A and B were $1.184 \times 10^{3}$ and $7.733 \times 10^{-3} \mathrm{~L} / \mathrm{mole} / \mathrm{cm}$, respectively. The sandell's sensitivity values were 0.129 and 0.020 for methods A and B respectively.

The limit of detection (LOD) is defined as the minimum level at which the analyte can be reliably detected for the two methods was calculated using the following equation

$$
\mathrm{LOD}=3.3 \mathrm{~s} / \mathrm{k}
$$

Where $s$ is the standard deviation of replicate determination values under the same conditions as for the sample analysis in the absence of the analyte and $\mathrm{k}$ is the sensitivity, namely the slope of the calibration graph. In accordance with the formula, the detection limits were found to be 4.92 and $0.56 \mu \mathrm{g} / \mathrm{mL}$ for method $\mathrm{A}$ and $\mathrm{B}$, respectively.

The limit of quantification (LOQ) is defined as the lowest concentration that can be measured with acceptable accuracy and precision

\section{$\mathrm{LOQ}=10 \mathrm{~s} / \mathrm{k}$}

According to this equation, the limit of quantification was found to be 14.89 and $1.69 \mu \mathrm{g} / \mathrm{mL}$ for Method A and B respectively; these parameters for the two methods are summarized in Table 2 .

Accuracy and precision: The accuracy and precision of the 


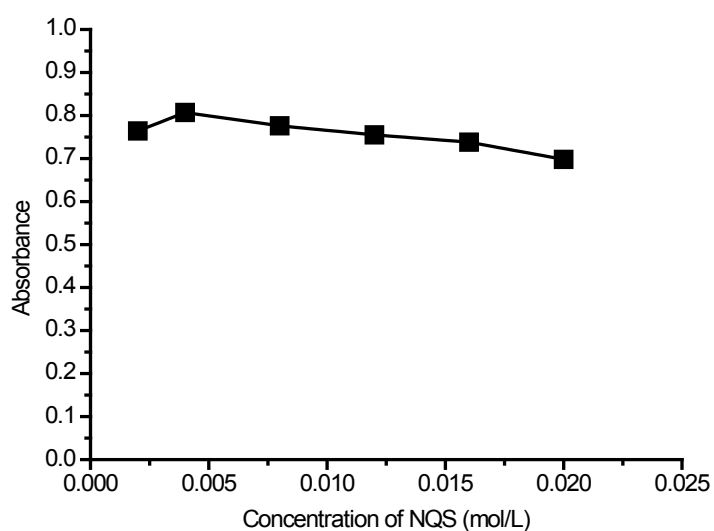

Figure 6: Effect of NQS concentration on the reaction with $\mathrm{MSZ}(20 \mu \mathrm{g} / \mathrm{mL}$ of MSZ, $1.0 \mathrm{~mL}$ buffer solution ( $\mathrm{pH} 12.0), 1.0 \mathrm{~mL}$ of NQS, at room temperature $\left(25^{\circ} \mathrm{C}\right)$ and reaction time $10 \mathrm{~min}$.

\begin{tabular}{|l|c|c|}
\hline Condition & Method A & Method B \\
\hline $\mathrm{pH}$ & 8 & 12 \\
\hline Buffer volume (ml) & 2 & 1 \\
\hline Temperature (C) & 40 & 25 \\
\hline Reaction time (min) & 10 & 10 \\
\hline Reagent concentration mole/L & $15 \times 10^{-3}$ & $4 \times 10^{-3}$ \\
\hline
\end{tabular}

Table 1: Optimum conditions for the reactions of two methods.

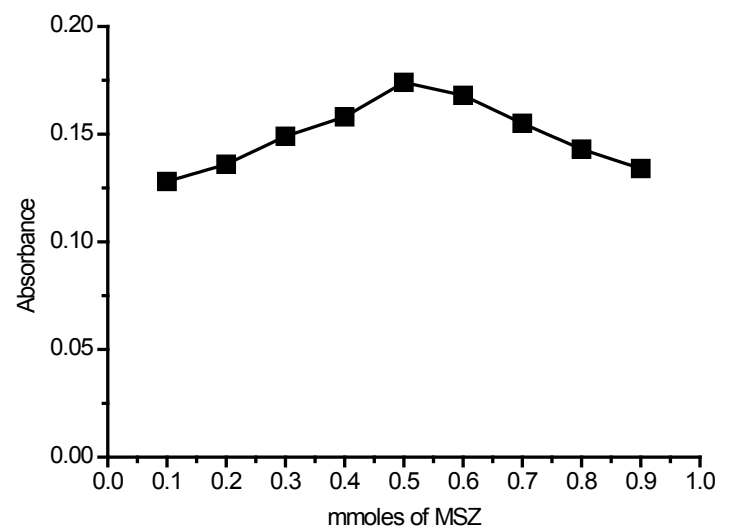

Figure 7: Job's method for the reaction of MSZ with ARS, $2.0 \mathrm{~mL}$ buffer solution ( $\mathrm{pH} 8$ ), at $40^{\circ} \mathrm{C}$, and reaction time $10 \mathrm{~min}$.

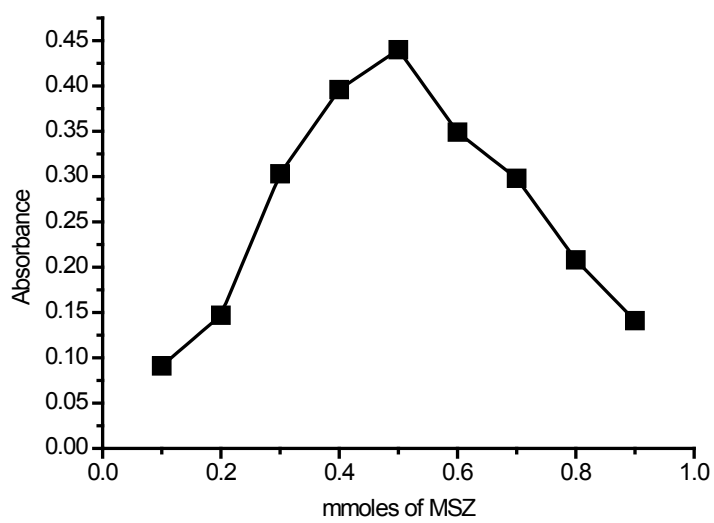

Figure 8: Job's method for the reaction of MSZ with NQS, $1.0 \mathrm{~mL}$ buffer solution $(\mathrm{pH} 12)$, at room temperature $\left(25^{\circ} \mathrm{C}\right)$ and reaction time $10 \mathrm{~min}$.<smiles>COc1cc2c(c(O)c1O)C(=O)c1ccccc1C2=O</smiles>

Radical cation

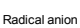

Scheme 1: Proposed reaction pathway between MSZ and ARS<smiles>CC(C)=CC(=O)NC1=C2C=CC=CC2C(=O)CC(=O)C1=NO</smiles>

Scheme 2: Proposed reaction pathway between MSZ and NQS.

\begin{tabular}{|l|c|c|}
\hline Parameters & Method A & Method B \\
\hline Linear range $(\mu \mathrm{g} / \mathrm{mL})$ & $15-97.5$ & $2-22$ \\
\hline limit of detection, $\mathrm{LOD}(\mu \mathrm{g} / \mathrm{mL})$ & 4.92 & 0.56 \\
\hline Limit of quantification, $\mathrm{LOQ}(\mu \mathrm{g} / \mathrm{mL})$ & 14.89 & 1.69 \\
\hline Slope & 0.00705 & 0.0426 \\
\hline Intercept & 0.01055 & 0.01944 \\
\hline Correlation coefficient $(\mathrm{r})$ & 0.99862 & 0.99971 \\
\hline Molar absorptivity $\varepsilon\left(\mathrm{L} \mathrm{mol}^{-1} \mathrm{~cm}^{-1}\right)$ & $1.184 \times 10^{3}$ & $7.733 \times 10^{3}$ \\
\hline Sandell sensitivity & 0.129 & 0.020 \\
\hline
\end{tabular}

Table 2: Summary of quantitative parameters and statistical data using the proposed procedure.

\begin{tabular}{|c|c|c|c|}
\hline Method & Concentration $(\boldsymbol{\mu g} / \mathbf{m L})$ & Recovery $(\% \pm \mathbf{R S D})^{*}$ & Relative error $\%$ \\
\hline \multirow{3}{*}{ Method A } & 30 & $101.24 \pm 0.890$ & -1.24 \\
& 60 & $97.27 \pm 0.237$ & -2.73 \\
\hline \multirow{3}{*}{ Method B } & 90 & $100.36 \pm 0.309$ & -0.37 \\
& 6 & $96.85 \pm 1.87$ & -0.031 \\
& 12 & $102.81 \pm 0.37$ & 0.028 \\
\hline \multirow{2}{*}{ then } & 18 & $99.23 \pm 2.31$ & -0.037 \\
\hline
\end{tabular}

*three determinations were used for the proposed methods

Table 3: Precision results for the proposed methods.

proposed method were determined at three concentration levels of MSZ (within the linear range) by analyzing three replicate analyses on pure drug of each concentration. The percentage relative error as accuracy and percentagerelative standard deviations (RSD) as precision for the results did not exceed $2.5 \%$ for the two methods as shown in Table 3, indicating the good reproducibility and repeatability of the two methods. This good level of precision and accuracy was suitable for quality control analysis of MSZ in their pharmaceutical formulation.

Robustness: Robustness was examined by evaluating the influence of small variation in the method variables on its analytical performance. In these experiments, one parameter was changed whereas the others were kept unchanged, and the recovery percentage was calculated each 


\begin{tabular}{|c|c|c|c|}
\hline Method A Condition & Recovery \pm RSD* & Method B Conditio & Recovery \pm RSD \\
\hline $\begin{array}{l}\mathrm{pH} \\
7.8 \\
8.2\end{array}$ & $\begin{array}{l}100.61 \pm 1.791 \\
99.82 \pm 0.902\end{array}$ & $\begin{array}{l}\mathrm{pH} \\
11.8 \\
12.2\end{array}$ & $\begin{array}{l}101.62 \pm 1.326 \\
102.01 \pm 1.762\end{array}$ \\
\hline $\begin{array}{l}\text { Temperature }\left({ }^{\circ} \mathrm{C}\right) \\
35 \\
45\end{array}$ & $\begin{array}{l}100.92 \pm 0.893 \\
103.44 \pm 1.308\end{array}$ & $\begin{array}{l}\text { Temperature }\left({ }^{\circ} \mathrm{C}\right) \\
20 \\
30\end{array}$ & $\begin{array}{l}104.83 \pm 2.790 \\
102.28 \pm 1.968\end{array}$ \\
\hline $\begin{array}{l}\text { Time }(\min ) \\
8 \\
12\end{array}$ & $\begin{array}{l}98.72 \pm 0.456 \\
99.19 \pm 0.454\end{array}$ & $\begin{array}{l}\text { Time }(\min ) \\
8 \\
12\end{array}$ & $\begin{array}{l}103.34 \pm 1.305 \\
103.37 \pm 1.735\end{array}$ \\
\hline $\begin{array}{l}\text { ARS concentration } \\
\text { (mole/L) } \\
14.8 \times 10^{-3} \\
15.2 \times 10^{-3}\end{array}$ & $\begin{array}{l}102.66 \pm 1.318 \\
98.09 \pm 0.459\end{array}$ & $\begin{array}{l}\text { ARS concentration } \\
\text { (mole/L) } \\
3.8 \times 10^{-3} \\
4.2 \times 10^{-3}\end{array}$ & $\begin{array}{l}100.84 \pm 1.336 \\
98.49 \pm 2.278\end{array}$ \\
\hline
\end{tabular}

*value are mean of three determinations

Table 4: Robustness of the proposed methods.

\begin{tabular}{|c|c|c|c|c|}
\hline Method & $\begin{array}{l}\text { Brand name and } \\
\text { dosage form }\end{array}$ & $\begin{array}{l}\text { Labeled claim } \\
500 \mathrm{mg}\end{array}$ & Amount found & ( $\%$ found $\pm \mathrm{RSD}$ )* \\
\hline Method A & Pentasa & 500 & 488.85 & $97.77 \pm 0.46$ \\
\hline Method B & - & _ & 490.85 & $98.17 \pm 1.70$ \\
\hline
\end{tabular}

*Three determinations were used for the proposed method

Table 5: Determination of MSZ in tablets by the proposed methods.

time. It was found that small variation in the methods variables did not significantly affect the procedures. This provided an indication of the reliability of the proposed methods during routine work; recovery values were shown in Table 4.

Applications of the methods: The proposed methods were applied to the pharmaceutical formulation containing MSZ. The results are shown in Table 5. Indicate the high accuracy of the proposed methods for the determination of the studied drug. The proposed methods have the advantage of being virtually free from interferences by excipients. The percentages were $97.77 \pm 0.46$ and $98.17 \pm 1.67$ for method $\mathrm{A}$ and $B$, respectively (Table 5).

\section{Conclusions}

The development spectrophotometric methods for the determination of MSZ in pharmaceutical formulation are simple, sensitive, rapid and accurate. The methods are superior to the previously reported spectrophotometric methods [14-20] in terms of the simplicity and sensitivity. The methods are practical and valuable for routine application in quality control laboratories for analysis of MSZ.

\section{References}

1. Actis GC, Pellicano R, Rizzetto M, Ayoubi M, Leone N, et al. (2009) Individually administered or co-prescribed thiopurines and mesalamines for inflammatory bowel disease. World J Gastroenterol 15: 1420-1426.

2. GonÃßalves E, Almeida LM, Dinis TC (1998) Antioxidant activity of 5-aminosalicylic acid against peroxidation of phosphatidylcholine liposomes in the presence of alpha-tocopherol: a synergistic interaction? Free Radic Res 29: 53-66.

3. Sandborn WJ, Feagan BG, Lichtenstein GR (2007) Medical management of mild to moderate Crohn's disease: evidence-based treatment algorithms for induction and maintenance of remission. Aliment Pharmacol Ther 26: 9871003.

4. Palumbo G, Carlucci G, Mazzeo P (1995) Simultaneous determination of 5-aminosalicylic acid, acetyl-5-aminosalicylic acid and 2,5-dihydroxybenzoic acid in endoscopie intestinal biopsy samples in humans by high-performance liquid chromatography with electrochemical detection. J Pharm Biomed Anal Oxford 14: 175-180.

5. Zadeh HA, Kohansal S (2012) Determination of mesalazine by spectrofluorometry in human serum after solid- phase extraction with $\mathrm{Ni}$-Al layered double hydroxide as a nanosorbent. J Braz Chem Soc 23: 473-481.
6. Gotti R, Pomponio R, Bertucci C, Cavrini V (2001) Determination of 5-aminosalicylic acid related impurities by micellar electrokinetic chromatography with an ion-pair reagent. J Chromatogr A 916: 175-183.

7. Nigovic B, Simunic B (2003) Determination of 5-aminosalicylic acid in pharmaceutical formulation by differential pulse voltammetry. J Pharm Biomed Anal 31: 169-174.

8. Haney PW, Dash AK (1997) Simple liquid chromatographic method for the analysis of 5 -aminosalicyclic acid and its degradation product $\mathrm{J}$ Chromatogr A 765: 233- 239 .

9. Palumbo G, Bacchi S, Primavera L, Palumbo P, Carlucci G (2005) A validated HPLC method with electrochemical detection for simultaneous assay of 5 -aminosalicylic acid and its metabolite in human plasma. Biomed Chromatogr 19: 350-354.

10. Hussain FN, Ajjan RA, Moustafa M, Anderson JC, Riley SA (1998) Simple method for the determination of 5-aminosalicylic and $\mathrm{N}$-acetyl-5-aminosalicylic acid in rectal tissue biopsies. J Chromatogr B Biomed Sci Appl 716: 257-266.

11. Bystrowska B, Nowak J, Brandys J (2000) Validation of a LC method for the determination of 5-aminosalicylic acid and its metabolite in plasma and urine. $J$ Pharm Biomed Anal 22: 341-347.

12. Nobilis M, Vybiralova Z, Sladkova K, Lisa M, Holcapek M, et al. (2006) Highperformance liquid-chromatographic determination of 5-aminosalicylic acid and its metabolites in blood plasma. J Chromatogr A 1119: 299-308.

13. Pastorini E, Locatelli M, Simoni P, Roda G, Roda E, et al. (2008) Development and validation of a HPLC-ESI-MS/MS method for the determination of 5 -aminosalicylic acid and its major metabolite $\mathrm{N}$-acetyl-5-aminosalicylic acid in human plasma. J Chromatogr B Analyt Technol Biomed Life Sci 872: 99-106.

14. Acharjya SK, Sahu A, Das S, Sagar P, Annapurna MM (2010) Development and Validation of Spectrophotometric methods for the Estimation of Mesalamine in Pharmaceutical Preparations. J Pharm Educ Res 11: 63-67.

15. Darak V, Karadi AB, Arshad MD, Appalraju S (2011) Derivative Spectroscopic Determination of Mesalamine in Tablets dosage forms. Pharma science monitor 2: 31-35.

16. Madhavi V, Panchakshari V, Prathyusha TN, Sekaran CB (2011) Spectrophotometric Determination of Mesalamine in Bulk and Tablet dosage forms based on Diaz-coupling reaction with Resorcinol. International journal of pharmaceutical sciences review and research 105-109.

17. Moharana AK, Banerjee M, Panda S, Muduli JN (2011) Development and validation of UV spectrophotometric method for the determination of Mesalamine in bulk and tablet formulation. International Journal of Pharmacy and Pharmaceutical Sciences 3:19-21.

18. Rohitas M, Agrawal A, Jain AK, Lariya NK, Kharya AK, et al. (2010) Development of Simultaneous Spectrophotometric Method of Mesalazine and Prednisolone in Same Dosage Form. Int J ApplPharm 2: 8-11.

19. Srikanth K, Emmanuel KA, Raju Rasayan RK (2010) Spectrophotometric determination of oxybutynin chloride through lon association complex formation. Rasayan J Chem 3: 179-187.

20. Basavaiah K, SriLatha, Swamy JM (1999) Spectrophotometric determination of ceterizine hydrochloride with Alizarin Red S. Talanta 50: 887-892.

21. Job P (1964) Advanced Physicochemical Experiments, 2nd Ed., Edinburgh Oliner and Boyd 54

22. Kishore M, Rao YH, Janardhan M (2010) Rapid determination of Ziprasidone and Buclizine Hydrochloride in pharmaceutical formulations (Tabletes) by simple spectrophotometric method. International Journal of Pharma Sciences and Research 1: 438-444.

23. Farhadi K, Savojbolaghi AK, Maleki R (2003) Study of Reactions of Triiodide and Alizarin Red $S$ with Some Important Phenothiazines. Development of an Indirect Titrimetric and a Spectrophotometric Method for the Assay of Phenothiazine Derivatives Journal of the Chinese Chemical Society 50: 153 159 .

24. Gouda AA, E Sheikh R, El-Azzazy RM (2012) Charge Transfer Spetrophotometric Determination of Zolmitriptan in Pure and Dosage Forms Analytical and Bioanalytical Techniques 3: 6.

25. Hassan WS, E-Henawee MM, Gouda AA (2008) Spectrophotometric determination of some histamine $\mathrm{H} 1$-antagonists drugs in their pharmaceutical preparations. Spectrochim Acta A Mol Biomol Spectrosc 69: 245-255. 
Citation: Alasha Abdalla FA, Elbashir AA (2014) Development and Validation of Spectrophotometric Methods for the Determination of Mesalazine in Pharmaceutical Formulation. Med chem 4: 361-366. doi:10.4172/2161-0444.1000166

26. Elbashir AA, Abdalla FAA (2013) Application of alizarin red S as an ion-pair reagent for the spectrophotometric determination of Olopatadine Hydrochloride in pharmaceutical formulation. American Academic \& Scholarly Research Journal 5: 22-30

27. Wang H.Y, Xu LX, Xiao Y (2004) Spectrophotometric determination of ampicillin sodium in pharmaceutical products using sodium 1,2-naphthoquinone-4 sulfonic as the chromogentic reagent. Spectrochim Acta Part A 60: 2933-2939.

28. Darwish IA (2005) Kinetic spectrophotometric methods for determination of trimetazidine dihydrochloride. Anal Chim Acta 551: 222-231.

29. Ebraheem SAM, Elbashir AA, Aboul-Enein HY (2011) Spectrophotometric methods for the determination of gemifloxacin in pharmaceutical formulations. Acta Pharmaceutica Sinica B 4: 248-253.

30. Elbashir AA, Elwagee HEA (2012) Spectrophotometric determination of pyrimethamine (PYM) in pharmaceutical formulation using 1,2-naphthoquinone4-sulfonate (NQS). JAAUBAS 11: 32-36.
31. Elbashir AA, Ahmed SM, Aboul-Enein HY (2012) New spectrofluorimetric method for determination of cephalosporins in pharmaceutical formulations. $J$ Fluoresc 22: 857-864.

32. Ali Ahmed SM, Elbashir AA, Suliman FE, Aboul-Enein HY (2013) New spectrofluorimetric method for determination of cephalosporins in pharmaceutical formulations. Luminescence 28: 734-741.

33. Ali Ahmed SM, Elbashir AA, Aboul-Enein HY (2011) New spectrophotometric method for determination of cephalosporins in pharmaceutical formulations Arab. J Chem 10.1016/ j. arabjc. 2011.08.012.

34. Elbashir AA, Ahmed AA, Ali Ahmed SM, Aboul-Enein HY (2012)1,2-Naphthoquinone-4-Sulphonic Acid Sodium Salt (NQS) as an Analytical Reagent for the Determination of Pharmaceutical Amine by Spectrophotometry. Appl. Spectrosc. Reviews 47: 219-232.

35. Elbashir AA, Awad SF (2013) A New Spectrophotometric Method for Determination of Penicillamine in Pharmaceutical Formulation Using 1 2-naphthoquine-4-sulfonate (NQS). J Pharmacovigilance 1:2. 